Journal Home Page:

http://perlinguam.journals.ac.za

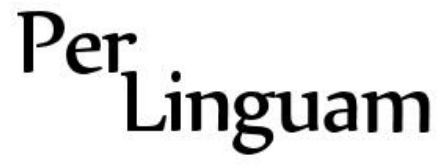

A Journal for Language Learning Tydskrif vir Taalaanleer

\title{
PRODUCTIVE KNOWLEDGE OF COLLOCATIONS MAY PREDICT ACADEMIC LITERACY
}

Tobie van Dyk, North-West University (Potchefstroom campus)

Henk Louw, North-West University (Potchefstroom campus)

Déogratias Nizonkiza, North-West University (Potchefstroom campus) and McGill University

Kris van de Poel, University of Antwerp and North-West University (Potchefstroom campus)

The present study examines the relationship between productive knowledge of collocations and academic literacy among first year students at North-West University. Participants were administered a collocation test, the items of which were selected from Nation's (2006) word frequency bands, i.e. the 2000-word, 3000-word, 5000-word bands; and the Academic Word List (Coxhead, 2000). The scores from the collocation test were compared to those from the Test of Academic Literacy Levels (version administered in 2012). The results of this study indicate that, overall, knowledge of collocations is significantly correlated with academic literacy, which is also observed at each of the frequency bands from which the items were selected. These results support Nizonkiza's (2014) findings that a significant correlation between mastery of collocations of words from the Academic Word List and academic literacy exists; which is extended here to words from other frequency bands. They also confirm previous findings that productive knowledge of collocations increases alongside overall proficiency (cf. Gitsaki, 1999; Bonk, 2001; Eyckmans et al., 2004; Boers et al., 2006; Nizonkiza, 2011; among others). This study therefore concludes that growth in productive knowledge of collocations may entail growth in academic literacy; suggesting that productive use of collocations is linked to academic literacy to a considerable extent. In light of these findings, teaching strategies aimed to assist first year students meet academic demands posed by higher education and avenues to explore for further research are discussed. Especially, we suggest adopting a productive oriented approach to teaching collocations, which we believe may prove useful.

Keywords: collocations, productive knowledge, academic literacy, word frequency

\section{INTRODUCTION}

Those involved in higher education have placed academic literacy at the centre of their research attention since the 1960s (cf. Van Dyk \& Van de Poel, 2013 among others). They were mainly concerned with the question of how to enhance higher education students' academic acculturation process and thus enable them to meet the academic challenges that higher education poses (Van Dyk, 2005; Van de Poel, 2006; Van de Poel \& Gasiorek, 2007; Weideman, 2007; Van der Walt, 2011; Scholtz, 2012; Van Dyk \& Van de Poel, 2013). Testing all the students entering universities has become common practice worldwide, which is aimed to assess their preparedness to cope with academic demands in higher education (Scholtz, 2012). This could be roughly considered as forming part of academic literacy, which has been defined as consisting 
mainly of three core components. The latter include reading skills, writing skills, and critical thinking which for many scholars should be considered as integrated (cf. Weideman, 2007, 2014; Grabe \& Zhang, 2013). Furthermore, empirical evidence seems to indicate that academic literacy could determine students' success in higher education (cf. Van Dyk, 2005 among others). However, in one study, Master's students 'explicitly indicated that developing academic literacy skills is a slow process from the first realisation that literacy skills matter to gradually building an academic identity during which learning by doing prevails' (Van de Poel \& Gasiorek, 2012: 64). Furthermore, the available literature suggests that attempts to assess and predict academic success have established a relationship between students' vocabulary and their academic literacy. Especially, a firm relationship has been established between vocabulary size - the number of words students know (Henriksen (1999) - and the reading component of academic literacy (Laufer, 1997; Nation, 2001, 2006; Qian, 2002; and Brunfaut, 2008 for a componential view) and academic literacy as a whole (Nizonkiza \& Van Dyk, 2015). For now, there is common belief that vocabulary knowledge constitutes an important part of literacy.

Researchers tend to agree that vocabulary is an essential component of literacy development and that word comprehension contributes enormously to language processing and virtually to language use (production) (Meara, 2002). However, very little evidence, if at all, is available with regard to the relationship between language use (productive collocations in this case) and academic literacy. This is an issue worth raising, which has remained unsolved so far. Collocations are defined in section 2.1; here suffice it to say that collocations are co-occurring words such as say a prayer, draw a conclusion, make a mistake, do justice, and lose count rather than *tell a prayer, *pull a conclusion, *do a mistake, *make justice and *drop count (Gyllstad, 2007: 1-2) and which are the preference of native speakers. Academic success in higher education does not only require word comprehension, but also and more importantly language production, especially fluency in production, such as evidenced in the use of collocations. For example, students are likely to be marked down for using a deviant collocation, which Hill (1999: 5) puts in the following terms, 'students with good ideas often lose marks because they don't know the four or five most important collocations of a key word that is central to what they are writing about'.

The latter proved to be important for both general use (Pawley \& Syder, 1983; Wray, 2002) and academic environments (Gledhill, 2000; Paquot, 2008). Thus, given the central role attributed to collocations today as 'an essential component of the production of language, potentially more significant than grammar' (Barnbrook, Mason \& Krishnamurthy, 2013: 51), and the predictive power of academic literacy for success in higher education (Van Dyk, 2005), it makes sense to test the relationship between collocations and academic proficiency/literacy; the ultimate objective of which is to inform pedagogy. Today, researchers agree that collocations should be taught explicitly in second and foreign language learning contexts, but they are confronted with the question of exactly which collocations to teach at the different learning stages (cf. Granger \& Meunier, 2008; Nizonkiza \& Van de Poel, 2014). Thus, testing collocations knowledge in association with linguistic proficiency and academic literacy may prove useful in this regard.

Nizonkiza (2014) tackled this issue by exploring the relationship between academic literacy and collocations, the target words of which were selected from Coxhead's (2000) Academic Word List (AWL). He found that first-year university students' productive knowledge of collocations 
positively and moderately correlated with their academic literacy. He, however, observed that performance on collocations was poor. As the literature indicates that the AWL covers only about $10 \%$ of a running text, we agree with Nizonkiza (2014) and Nizonkiza, Van Dyk \& Louw (2013) regarding the need to explore the same relationship at wider word coverage. Nizonkiza (2014) and Nizonkiza et al. (2013) recommended testing the relationship between academic literacy and productive knowledge of collocations with words selected from more word frequency bands. This study thus attempts to map knowledge of collocations onto students' academic literacy level in order 'to explore whether knowledge of collocations develops in correlation with academic literacy'. We believe that establishing a link between academic literacy and collocations, i.e. finding 'whether the groups identified as academically at-risk by the TALL [Test of Academic Literacy Levels] or TAG [Toets van Akademiese Geletterdheidsvlakke], its Afrikaans counterpart, are also identified as such by their collocation test scores. This could allow us to 'suggest specific collocations to teach, depending on the students' performances on the collocation test, in the same way that the TALL/TAG is used to influence the content of the academic literacy courses' (Nizonkiza et al., 2013: 174).

Given the importance associated with frequency in word knowledge, proficiency, and literacy development; we agree with Nizonkiza (2014) and Nizonkiza et al. (2013) that in addition to the AWL, other word bands, particularly Nation's (2006) 3000 most frequent words should be attended to for productive use. According to Nation (1990, 2006), higher education students need a productive vocabulary of around 3000 high-frequency words in addition to the AWL. Schmitt \& Schmitt (2014) echoed this suggestion in placing the cut-off point of frequent words at the 3000-word band. Furthermore, research on vocabulary which has associated receptive knowledge of words (the number of words understood), considering word frequency, with linguistic proficiency has proven useful with regard to the number of words to teach and their frequency bands following learning stages of the learners (Laufer, 1998; Schmitt, Schmitt \& Clapham, 2001). We believe that academic literacy modules could be informed in a similar fashion should a relationship be established between mastering collocations from different word bands and academic literacy.

With the above insights in mind, this study asks the following research questions:

(i) To what extent does productive knowledge of collocations predict academic literacy?

(ii) Does academic literacy increase with productive knowledge of collocations at the different frequency bands?

It is hoped that answering these questions will contribute to our understanding of the relationship between collocations and academic literacy. Shedding new light on the link between written productive knowledge of collocations will possibly benefit ESL students in their academic endeavour.

\section{LITERATURE STUDY}

\section{Types of collocations}

The meaning of the term collocation, since its borrowing into English around the $16^{\text {th }}$ century, has varied a great deal and still varies considerably in its use (Barnbrook et al., 2013). From an 
evolutionary perspective, collocation is used in the three followings ways: (i) 'to describe the way words group together in their normal use in texts'; (ii) 'to describe the analysis tool used to explore this grouping and to assess its significance and implications', and (iii) 'more controversially, to describe an aspect of language production in which pre-fabricated chunks of language are used to build up utterances' (Barnbrook et al., 2013: 3). This means that a commonly agreed on definition is missing. What is obvious, however, is that research on collocations in second/foreign language contexts, which fits our own research and teaching context, has followed two different, but overlapping traditions commonly known as the frequency-based and the phraseological approaches ${ }^{1}$ (Nesselhauf, 2005; Granger \& Paquot, 2008; Gyllstad, 2007; Barfield \& Gyllstad, 2009; Barnbrook et al., 2013). The former considers frequency as the main criterion for defining a collocation while the latter considers the syntactic category of collocations' constituents, their transparency in meaning, and the degree to which cooccurring words can be substituted by others as the main criteria for defining collocations.

Within this tradition, a somewhat different and more detailed approach comes from Benson et al. (1986, 1997) who suggest adopting a structural approach to collocations. For them a collocation is determined by a structure and occurs in patterns involving lexis and grammar. They therefore classed collocations into two categories, i.e. lexical and grammatical collocations, which formed the basis for The BBI Combinatory Dictionary of English. Lexical collocations on the one hand consist of seven main categories: verb-noun (e.g. break a code), verb-adverb (e.g. affect deeply), adjective-noun (e.g. heavy drinker), noun-verb (e.g. water freezes), noun-noun (e.g. sense of pride), verb + expression with preposition (e.g. filled with horror), and adverb-adjective (e.g. closely related). Grammatical collocations on the other hand consist of a main lexical word (a noun, adjective, verb, or adverb) plus a preposition (e.g. by accident) or that-clause (e.g. an agreement that), or a to-infinitive clause (e.g. need to) and a total of eight types has been identified. The present study adopts this typology and will study one of the lexical collocations, i.e. verb-noun collocations in the way they are defined in the Oxford collocations dictionary for students of English: 'the way words combine in a language to produce natural-sounding speech and writing' (Lea at al., 2002: vii). This collocations dictionary was chosen for the same reasons explained in Nizonkiza (2012: 102) that '(i) it was designed as a learning tool; (ii) it was compiled on the basis of the BNC (frequency of collocations was checked from the corpus); (iii) it contains sentences from the $\mathrm{BNC}$, or with minor modifications aimed at making them more accessible for learners, without altering the meaning of the collocations' (BNC stands for the British National Corpus). It should be noted that the collocation dictionary also considers frequency as a criterion for defining collocations, which makes the present study fall in the emerging approach to collocations, which adopts a conciliatory tone and suggests considering elements from the two main traditions to define collocations (cf. Nesselhauf, 2005; Gyllstad, 2007).

\section{Importance of collocations}

Collocations have attracted increased research attention since the 1990s, a period in which research on vocabulary grew in popularity (cf. Read, 2000). Today, they are considered as an important component of language in EFL and ESL contexts. Among other things, research has

\footnotetext{
${ }^{1}$ It should be noted that our examples are in English since it is the language which has been widely investigated in this regard and the target language in this research.

Per Linguam 2016 32(2):66-81

http://dx.doi.org/10.5785/32-2-601
} 
indicated that collocations help EFL and ESL learners sound more natural and achieve a nativelike fluency (Pawley \& Syder, 1983; Wray, 2002). Collocations are also believed to characterize fluent writing (Gledhill, 2000; Nation, 2001; Nesselhauf, 2005; Paquot, 2008). Especially, a number of studies have established a relationship between using collocations - productive knowledge - and overall linguistic proficiency (cf. Gitsaki, 1999; Bonk, 2001; Eyckmans et al., 2004; Boers et al., 2006; Nizonkiza, 2011). This relationship holds at the receptive level as well (Gyllstad, 2007). These studies have demonstrated with empirical evidence that more proficient students master more collocations. What is particularly interesting and worth pointing out is that even though these studies were conducted on participants from different backgrounds and learning stages, they seem to point to the same general tendency that more proficient students use more collocations. Students involved in these studies, for instance, include Greek students of English selected from three different proficiency levels (Gitsaki, 1999), Belgian students of English from an advanced proficiency level (Eyckmans et al., 2004; Boers et al., 2006), Burundian students of English from three different proficiency levels (Nizonkiza, 2011), Swedish learners of English from four different proficiency levels (Gyllstad, 2007). But, most of them if not all established a relationship between overall linguistic proficiency and mastery of collocations. Following this proven importance of collocations, several calls to teach second and foreign languages with an explicit focus on collocations have been made. It is important to note that most EFL and ESL practitioners agree on this and have responded with a number of practical examples on how to teach collocations ${ }^{2}$.

\section{Academic literacy and the need for intervention}

Academic literacy has witnessed increased research attention for nearly six decades now (cf. Butler, 2013). It has been approached from different angles, and does not seem to be a straightforward concept (cf. Butler, 2013; Van Dyk \& Van de Poel, 2013). So far, there is no commonly agreed on definition of this concept, which Van Dyk \& Van de Poel (2013) attribute to the changing needs and learning environments in higher education. According to these scholars, higher education needs today differ from what they were ten years ago and surely with what they will be in ten years to come. In addition, higher education institutions have different needs, which they may address in different ways. This is exemplified in Van Dyk \& Van de Poel's definition (2013: 47) that academic literacy is 'the knowledge and skills required to communicate and function effectively and efficiently in different academic communities and achieve well-defined academic goals'. This idea of different academic communities supports Cliff \& Yeld's (2006: 19) view of academic literacy as 'students' capacities to engage successfully with the demands of academic study in the medium of instruction of the particular study environment'. These definitions allow some flexibility and clearly go beyond Weideman's (2007, 2014) and Grabe \& Zhang's (2013) core components of academic literacy mentioned in the introduction, i.e. reading skills, writing skills, and critical thinking.

Furthermore, academic literacy has been looked at in terms of competencies higher education students should possess. Van Dyk \& Weideman (2004) outlined a number of competencies higher education students are expected to have achieved for them to complete their university degrees successfully (see also Weideman, 2006). This has been one way of looking at academic

\footnotetext{
${ }^{2}$ For details on the suggestions on how to teach collocations, we refer the readers to the works reported in Barfield \& Gyllstad (2009).
}

Per Linguam 2016 32(2):66-81 http://dx.doi.org/10.5785/32-2-601 
literacy and Van Dyk \& Van de Poel (2013) updated these competencies ${ }^{3}$, which are also referred to as task-based (Van Dyk \& Van de Poel, 2013) or functional oriented (Butler, 2013).

The task-based competencies are also known as generic academic literacy. They are in parallel with two more approaches, viz skills-based and the acquisition of discipline-specific academic literacy practices approaches, as identified by Butler (2013). While the skills-based approach consists of what Weideman (2007) referred to as the core competencies, which are composed of the traditional language skills, viz reading and writing, and critical thinking; the disciplinespecific academic literacy practices approach is an increasing trend in academic literacy (Butler, 2013).

Even though a single definition of academic literacy does not seem to exist, all those involved in higher education agree that academic literacy development requires intervention. Examples of interventions include courses such as All write (Van de Poel \& Gasiorek, 2007) and Scribende (Van de Poel, 2006) offered at the University of Antwerp (Belgium), which are aimed to develop the writing component of academic literacy through reading. Basic skills in academic literacy (Van der Walt, 2011) and Academic literacy: Prepare to learn (Weideman, 2007), offered to university entrants at North-West University and University of Pretoria (South Africa), respectively; are aimed to develop academic literacy competencies as a whole. These bridging courses are aimed to remedy under-preparedness of some higher education students and in the South African context they seem to be based on the skill-based/functional oriented approach to academic literacy. For Butler (2013: 72), intervention should be 'an integral part of higher education where highly-trained professionals provide the best possible support to students in order to promote students' success'. His suggestion echoes Van de Poel \& Van Dyk's (2013) among others. Based on these propositions, it makes sense to take a systematic and wellresearched approach to determine the exact productive vocabulary knowledge of students, i.e. collocational competence in the present case, in order to advise on interventions more responsibly. The experiment reported in this article was conducted to this end.

\section{METHODOLOGY}

\section{Participants}

First-year students from different faculties and institutes of the North-West University, Potchefstroom campus, participated in this study. They consisted of two groups: group one $(\mathrm{N}=$ 53) registered for an introduction to academic literacy module (AGLE 111); a module lectured in English. Most of the participants from this group spoke different home languages (L1) and English was their second language (L2). The second group ( $\mathrm{N}=74)$ consisted of students who were also enrolled for an introduction to academic literacy module (AGLA 111), but lectured in Afrikaans, which is the native language of most of them. English was their L2; and both groups could be considered as having an additional exposure to English to varying degrees, mainly through newspapers, the internet, TV and radio as well as some of their text books. It was explained to the students that sitting the collocation test was meant for research purposes and that participating in the study was voluntary. Especially, they were informed that their

\footnotetext{
${ }^{3}$ For a detailed and critical evaluation of academic literacy competencies, we refer the reader to Van Dyk \& Van de Poel (2013).

Per Linguam 2016 32(2):66-81

http://dx.doi.org/10.5785/32-2-601
} 
participating/not participating in the study and their performance on the test would not affect their final grade in the course in any way. They were encouraged to participate, which they did.

\section{Collocation test}

For the present study, a collocation test aimed to measure productive knowledge of collocations (controlled) was presented to participants. The test adopted in this study was used in an earlier study (Nizonkiza, 2011). The design of the test was inspired by Laufer \& Nation's (1999) definition of controlled productive knowledge. They define controlled productive knowledge in the following terms:

The ability to use a word when compelled to do so by a teacher or researcher, whether in an unconstrained context such as a sentence writing task, or in a constrained context such as a fill in task where a sentence context is provided and the missing target word has to be supplied (Laufer \& Nation, 1999: 37).

In vocabulary testing, frequency of words is often considered as an important criterion for selecting test items. In the present study, the test items were selected from Nation's (2006) wordfrequency list - the 2000-word, 3000-word, 5000-word bands and the Academic Word List (Coxhead, 2000) and the type of collocations investigated is verb-noun combination. In each frequency band, 10 nouns (target words) were selected owing to Nation \& Beglar's (2007) suggestion. Their collocations (verbs) were selected from Lea et al.'s (2002) Oxford collocations dictionary for students of English. This collocation dictionary was chosen for the reasons explained in the Types of collocations section (second paragraph), and particularly because it provides contextual information in which the collocations are used. It was used for both collocates of the target words and the sentential contexts in which they were embedded. The collocations were selected by looking up the target nouns at the relevant entry in the collocation dictionary and selecting their verb collocations in the verb-noun combinations. A collocation sampler ${ }^{4}$ was used to determine the strength of collocation and in each case, the verb collocating with the noun more strongly than the others was retained for this study. Verb-noun collocations constitute the type of collocations examined in this study because the literature indicates that they pose challenges for L2 learners; they are by far the biggest type of collocation; and they contain the most important information while communicating (Gyllstad, 2007). Moreover, as people communicate, they tend to think of the noun first, which stands for the action they want to perform; and then the verb, standing for how to perform that action (Lea et al., 2002). Laufer \& Nation's (1999) test format was adopted, i.e. the target words were embedded in a sentential context.

As Laufer \& Nation (1999) suggest, the collocations were deleted with the first two letters provided, which was aimed at a cued recall. As appears in the example below, participants were instructed to fill in the missing word. The test was presented in English, the second language of participants since the literature indicates that collocations are problematic in L2, but not in the L1 contexts (Paquot, 2008).

\footnotetext{
${ }^{4}$ The collocation sampler. Available from http://www.collins.co.uk/Corpus/CorpusSearch.aspx [Accessed: 26 April 2009]
}

Per Linguam 2016 32(2):66-81

http://dx.doi.org/10.5785/32-2-601 
Instruction: Complete the underlined words in the sentences below.

Example: $\quad$ She is conducting campaigns to at....... new clients.

She is conducting campaigns to attract new clients.

\section{RESULTS}

\section{Productive knowledge of collocations predicts academic literacy}

The main question the present study addresses is the extent to which productive knowledge of collocations predicts academic literacy. In order to answer it, participants' scores on both TALL/TAG and the collocation test were correlated. The correlation coefficient is $367^{* *}$, which, according to Cohen (1988), is medium and statistically significant with a p-value of .000, significant at the 0.01 level (2-tailed). The predictive relationship between collocations and academic literacy was also exemplified by means of a graphic representation. As presented in Figure 1, it appears that students with higher scores in collocation are also at less risk of academic failure, which implies that increase in one entails increase in the other; which answers the first research question of this study.

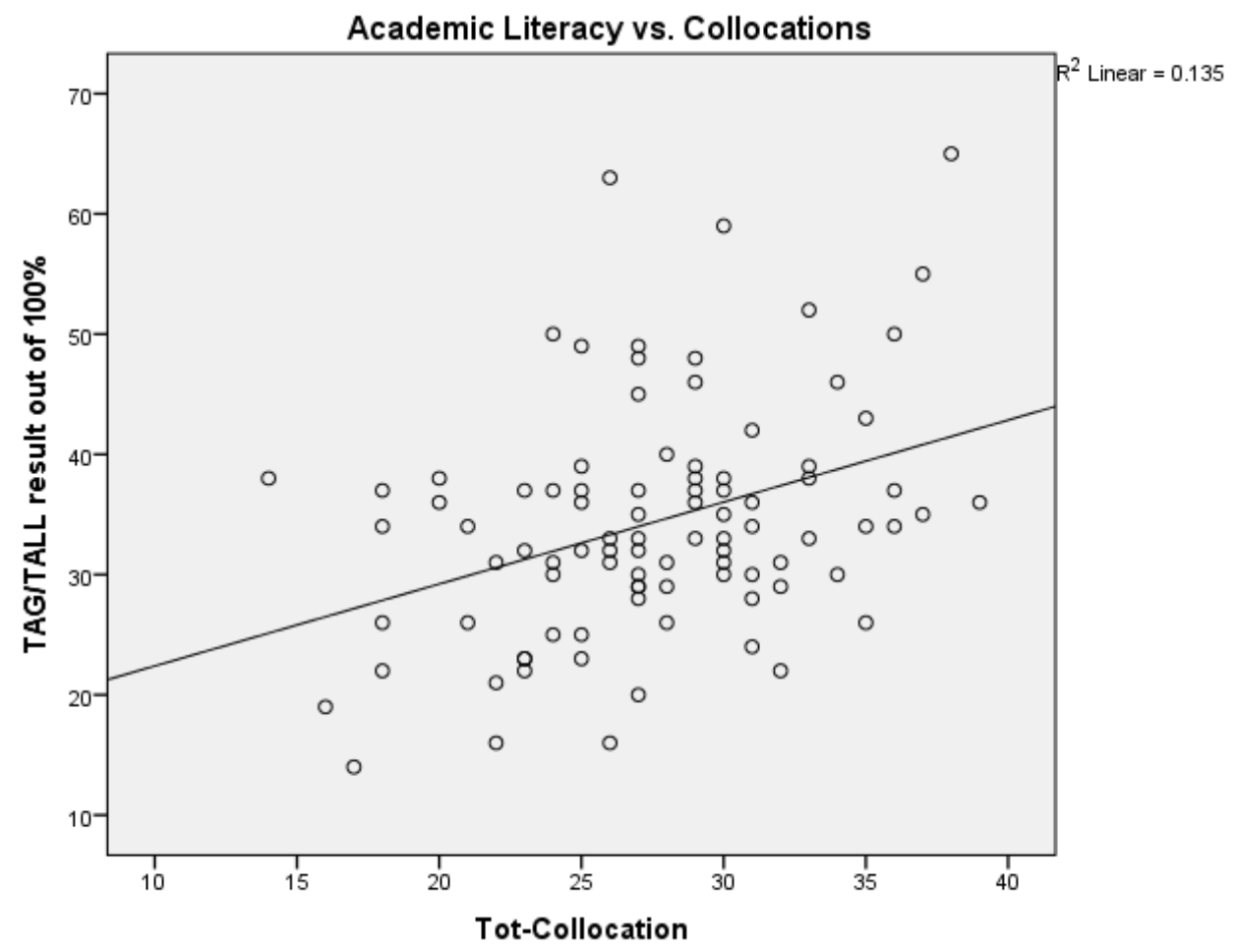

Figure 1. Growth of Collocations and Academic Literacy 


\section{Collocation growth at frequency bands correlates with academic literacy}

The second research question, which is corollary of the first one, is whether or not collocation increase at the different frequency bands can be related to academic literacy. This question was answered by correlating collocation scores at each frequency band with TALL/TAG scores. The correlation coefficients are: .199 at the 2000 -word; $.348^{* *}$ at the 3000 -word; $.348^{* * *}$ at the 5000word; and $.223^{*}$ at the AWL (cf. Appendix A for details on correlations). All of the correlations (except at the 2000-word band) are statistically significant to different degrees, which seems to indicate that mastery of collocations at each frequency band is correlated with academic literacy. For illustration, their graphic representations are presented in Appendix B. Even though we did not perform repeated measures in order to map scores achieved at each word band on the levels identified by the TALL/TAG following the low number of participants (we come back to this in the discussion and conclusion section), these results are indicative with regard to a possible parallel growth between academic literacy and collocations at each of the word bands, which answers the second research question.

\section{DISCUSSION AND CONCLUSION}

The present study explores the relationship between productive knowledge of collocations and academic literacy among first-year students at North-West University. The results indicate that, overall, knowledge of collocations is correlated with academic literacy, which is also observed at each of the frequency bands involved in the collocation test. Stated otherwise, these results could be interpreted as: growth in productive knowledge, operationalised through collocations here, entails growth in academic literacy. What this means is that students with a higher academic literacy level are the ones who can potentially productively use more collocations. The present study therefore concludes that use of collocations is linked to academic literacy to a significant extent.

This study forms part of a larger project aimed to examine the relationship between different aspects of vocabulary knowledge, especially collocations and academic literacy. It is interesting to note that the results it yields match those obtained in these earlier studies (Nizonkiza, 2014; Nizonkiza \& Van Dyk, 2015). Particularly, these results confirm the association between knowing collocations and academic literacy reported in Nizonkiza (2014); a study replicated and extended to a larger scope here. Nizonkiza (2014) investigated the relationship between written productive knowledge of collocations of academic vocabulary with target words selected from the AWL. This diagnostic study was aimed to gauge higher education ESL students' use of collocations of academic vocabulary and the extent to which their mastery could be related to academic literacy. Although performance on collocations was not high - an observation also confirmed in a subsequent study by Nizonkiza et al. (2013) - a moderate, but significant correlation between mastery of collocations and academic literacy was found. The present study thus extends this relationship between knowing collocations and academic literacy to general vocabulary, i.e. words from word bands other than academic vocabulary. This finding is quite revealing and corroborates previous findings that written productive knowledge of collocations grows alongside overall proficiency (cf. Gitsaki, 1999; Bonk, 2001; Eyckmans et al., 2004; Boers et al., 2006; Nizonkiza, 2011; among others). In other words, what appears to be an almost 
confirmed relationship between written productive knowledge of collocations and overall linguistic proficiency is here extended to academic literacy.

Furthermore, these results also complement earlier studies that explored the relationship between receptive knowledge of vocabulary and academic literacy. Especially, they confirm the results of a study conducted on the same group involved in this one, which tested students' vocabulary size in relation to their academic literacy (Nizonkiza \& Van Dyk, 2015). Results from this earlier study indicated that students with bigger vocabularies are the ones less at risk; results which align with those from studies that investigated the relationship between reading comprehension and academic literacy (Qian, 2002; Nation, 2006). The latter pointed to the observation that reading comprehension grows with academic literacy. The present study extends the findings from all these previous studies that established a relationship between academic literacy and vocabulary size on the one hand and reading comprehension on the other to written productive knowledge of collocations.

Knowing that previous studies that have established a relationship between knowing words (receptive knowledge) and overall proficiency or academic literacy have contributed to informing pedagogy - by for instance determining the number of words, their word bands or frequency and the threshold of words needed in higher education for comprehension - we wonder if we could not attempt the same from a productive point of view based on this newly established relationship (by our study). Higher education students need to understand both general and academic vocabulary; but more importantly, they have to master these words productively, which remains a considerable challenge as research seems to indicate (Paquot, 2008; Eyckmans, 2009).

A pedagogy based on the teaching of collocations would entail that the same way scholars are responding to the calls to explicitly teach collocations in ESL and EFL contexts, especially considering word frequency and learning stages (cf. Nizonkiza \& Van de Poel, 2014), collocations could form part of the aspects taught in academic literacy modules. We strongly argue in favour of this approach and we believe that informing academic literacy modules with written productive knowledge of collocations could largely contribute to students' success. Previous research has indicated that students are marked down because of failing to use appropriate collocations (Hill, 1999) and that collocations are more problematic at the productive level (cf. Eyckmans, 2009). In addition, from our own research/teaching context, most of the first-year students who participated in an earlier study (Nizonkiza et al., 2013) do not master collocations of frequent general and academic vocabulary. Thus, making collocations an integral component of academic literacy modules taught to the first-year students at North-West University seems to be warranted and could potentially be part of their pathway to academic success.

In order to determine exactly how many collocations to bring to the learners' attention and their sources in terms of target words, we suggest exploring this association between knowing collocations and academic literacy. Indeed, we initially planned to carry out an in-depth analysis of the relationship between academic literacy and collocations at the level of each word band and determine whether the groups identified as academically at-risk by the TALL/TAG are also identified as such by their collocation test scores. However, we could not do so because of the 
low number of participants. We therefore suggest replicating the study to include more participants - possibly from different learning stages. We believe that this will help gain more insight into the relationship between written productive knowledge of collocations and academic literacy and thereby contribute to developing academic literacy which is very much needed in higher education.

All in all, this study has demonstrated that written productive knowledge of collocations appears to increase alongside academic literacy. It is hoped that this study lays the basic ground-work for considering our suggestion to include collocations in academic literacy modules, or at least sparks a debate about the issue.

\section{REFERENCES}

BARFIELD, A \& H GYLLSTAD (Eds) 2009. Researching collocations in another language. New York: Palgrave Macmillan.

BARNBROOK, G, O MASON \& R KRISHNAMURTHY. 2013. Collocations: Applications and implications. Basingstoke: Palgrave Macmillan.

BENSON, M, E BENSON \& R ILSON. 1986. The BBI combinatory dictionary of English. Amsterdam: John Benjamins Publishing Company.

BENSON, M, E BENSON \& R ILSON. 1997: The BBI dictionary of English word combinations (Revised edition): Amsterdam: John Benjamins Publishing Company.

BOERS, F, J EYCKMANS, J KAPPEL, H STENGERS \& M DEMECHELEER. 2006. Formulaic sequences and perceived oral proficiency: Putting the Lexical Approach to the test. Language Teaching Research, 10(3): 245-261.

BONK, WJ. 2001. Testing ESL learners' knowledge of collocations. In HUDSON, T \& JD BROWN (Eds), A focus on language test development: Expanding the language proficiency construct across a variety of tests. Honolulu: University of Hawaii Second Language Teaching and Curriculum Center. 113-142.

BRUNFAUT, T. 2008. Foreign language reading for academic purposes. Students of English (native speakers of Dutch) reading English academic texts. Unpublished PhD dissertation, University of Antwerp.

BUTLER, G. 2013. Discipline-specific versus generic academic literacy intervention for university education: An issue of impact? Journal for Language Teaching, 47(2): 71-88.

CLIFF, AF \& N YELD. 2006. Test domains and constructs: Academic Literacy. In H GRIESEL (Ed), Access and entry level benchmarks: The National Benchmark Tests Project. Pretoria: Higher Education South Africa. 19-27.

COHEN, J. 1988. Statistical power analysis for the behavioral sciences. New Jersey: Lawrence Erlbaum Associates.

COXHEAD, A. 2000. A new Academic Word List. TESOL Quarterly, 34(2): 213-239.

EYCKMANS, J. 2009. Toward an assessment of learners' receptive and productive syntagmatic knowledge. In BARFIELD, A \& H GYLLSTAD (Eds), Researching collocations in another language. New York: Palgrave Macmillan. 139-152.

EYCKMANS, J, F BOERS \& M DEMECHELEER. 2004. The Deleted-Essentials Test: An effective and affective compromise. Available from www.hltmag.co.uk/nov04/mart04.htm [Accessed: 18 May 2013].

GITSAKI, C. 1999. Second language lexical acquisition: A study of the development of collocational knowledge. San Francisco: International Scholars Publications.

GLEDHILL, CJ. 2000. Collocations in science writing. Tubingen: Gunter Narr Verlag.

GRABE, W \& C ZHANG. 2013. Reading and writing together: A Critical component of English for academic purposes teaching and learning. TESOL Journal, 4(1): 9-24.

Per Linguam 2016 32(2):66-81

http://dx.doi.org/10.5785/32-2-601 
GRANGER, S. \& F MEUNIER (Eds) 2008. Phraseology. An interdisciplinary perspective. Amsterdam: John Benjamins Publishing Company.

GRANGER, S \& M PAQUOT. 2008. Disentangling the phraseological web. In GRANGER, S \& F MEUNIER (Eds), Phraseology. An interdisciplinary perspective. Amsterdam: John Benjamins Publishing Company. 27-49.

GYLLSTAD, H. 2007. Testing English collocations. Unpublished PhD dissertation, Lund University.

HENRIKSEN, B. 1999. Three dimensions of vocabulary development. Studies in Second Language Acquisition, 21(2): 303-317.

HILL, J. 1999. Collocational competence. ETP, 11, 4-7.

LAUFER, B. 1997. What is in a word that makes it hard or easy: Some intralexical factors that affect the learning of words. In SCHMITT, N \& M MCCARTHY (Eds), Vocabulary: Description, acquisition and pedagogy. Cambridge: Cambridge University Press. 140-155.

LAUFER, B. 1998. The development of passive and active vocabulary in a second language: Same or different? Applied Linguistics, 19(2): 255-271.

LAUFER, B \& ISP NATION. 1999. A vocabulary size test of controlled productive ability. Language Testing, 16(1): 33-51.

LEA, D, J CROWTHER \& S DIGNEN (Eds) 2002. Oxford collocations dictionary for students of English. Oxford: Oxford University Press.

MEARA, P. 2002. The rediscovery of vocabulary. Second Language Research, 18(4): 393-407.

NATION, ISP. 1990. Teaching and learning vocabulary. Rowley, MA: Newbury House.

NATION, ISP. 2001. Learning vocabulary in another language. Cambridge: Cambridge University Press.

NATION, ISP. 2006. How large a vocabulary is needed for reading and listening? Canadian Modern Language Review, 63(1): 59-82.

NATION, ISP \& D BEGLAR. 2007. A vocabulary size test. The Language Teacher, 31(7): 9-13.

NESSELHAUF, N. 2005. Collocations in a learner corpus. Amsterdam: John Benjamins Publishing Company.

NIZONKIZA, D. 2011. The relationship between controlled productive collocational competence and L2 proficiency. TTWiA, 84/85: 29-37.

NIZONKIZA, D. 2012. The relationship between lexical competence, collocational competence, and second language proficiency. Unpublished $\mathrm{PhD}$ dissertation, University of Antwerp.

NIZONKIZA, D. 2014. The relationship between productive knowledge of collocations and academic literacy among tertiary level learners. Journal for Language Teaching, 48(1): 149-171.

NIZONKIZA, D \& K VAN DE POEL. 2014. Teachability of collocations: The role of word frequency counts. Southern African Linguistics and Applied Language Studies, 32(1): 301-316.

NIZONKIZA, D \& T VAN DYK. 2015. Academic literacy of South African higher education level students: Does vocabulary size matter? Stellenbosch Papers in Linguistics, 44: 147-174.

NIZONKIZA, D, T VAN DYK \& H LOUW. 2013. First-year university students' productive knowledge of collocations. Stellenbosch Papers in Linguistics, 42: 165-181.

PAQUOT, M. 2008. Exemplification in learner writing: A cross-linguistic perspective. In GRANGER, S \& F MEUNIER (Eds), Phraseology in foreign language learning and teaching. Amsterdam: John Benjamins Publishing Company. 101-119.

PAWLEY, A \& FH SYDER. 1983. Two puzzles for linguistic theory: Nativelike selection and nativelike fluency. In RICHARDS, JC \& RW SCHMIDT (Eds), Language and communication. London: Longman. 191-227.

QIAN, DD. 2002. Investigating the relationship between vocabulary knowledge and academic reading performance: An assessment perspective. Language Learning, 52(3): 513-536.

READ, J. 2000. Assessing vocabulary. Cambridge: Cambridge University Press.

SCHMITT, N \& D SCHMITT. 2014. A reassessment of frequency and vocabulary size in L2 vocabulary teaching. Language Teaching, 47(4): 484-503. 
SCHMITT, N, D SCHMITT \& C CLAPHAM. 2001. Developing and exploring the behaviour of two new versions of the vocabulary levels test. Language Testing, 18(1): 55-88.

SCHOLTZ, D. 2012. Using the National Benchmark Tests in engineering diplomas: Revisiting generic academic literacy. Journal for Language Teaching, 46(1): 46-58.

VAN DE POEL, K. 2006. Scribende: Academic writing for students of English. Leuven: Acco.

VAN DE POEL, K \& J GASIOREK. 2007. All Write: An introduction to writing in an academic context. Leuven: Acco.

VAN DE POEL, K \& J GASIOREK. 2012. Academic acculturation: The case of writing in an EFL teaching and learning environment. Journal for Language Teaching, 46(2): 58-72.

VAN DE POEL, K \& T VAN DYK. 2013. Discipline-specific academic literacy and academic integration. Publication forthcoming in John Benjamins publication of the 2013 content and language integrated learning conference.

VAN DER WALT, JL. (Ed) 2011. Basic skills in academic literacy. Noordbrug: AndCork.

VAN DYK, T. 2005. Towards providing effective academic literacy intervention. Per Linguam, 21(2): 38-51.

VAN DYK, T \& K VAN DE POEL. 2013. Towards a responsible agenda for academic literacy: Considerations that will benefit students and society. Journal for Language Teaching, 47(2): 4370.

VAN DYK, T \& A WEIDEMAN. 2004. Switching constructs: On the selection of an appropriate blueprint for academic literacy assessment. Journal for Language Teaching, 38(1): 1-13.

WEIDEMAN, A. 2006. Assessing academic literacy in a task-based approach. Language Matters, 37(1): 81-101.

WEIDEMAN, A. 2007. Academic literacy: Prepare to learn. Pretoria: Van Schaik Publishers.

WEIDEMAN, A. 2014. Innovation and reciprocity in applied linguistics. Literator, 35(1). Available from http://www.literator.org.za/index.php/literator/article/view/1074/0 [Accessed: 6 September 2014].

WRAY, A. 2002. Formulaic language and the lexicon. Cambridge: Cambridge University Press.

\section{BIOGRAPHICAL NOTES}

Tobie van Dyk is the director of the Centre for Academic and Professional Language Practice in the School of Languages at the North-West University's Potchefstroom campus. His research focus is on applied linguistics, and in particular on academic literacy development and language testing.

Henk Louw is a senior lecturer at the Potchefstroom campus of the North-West University. He teaches Academic Literacy and has research interests in second language writing, feedback, and the implementation of technology for pedagogical purposes. He has assisted in the creation of the Backchat and MarkWrite software packages for feedback.

Déogratias Nizonkiza is a Postdoctoral researcher at the School of Languages, North-West University, Potchefstroom campus; investigating the relationship between knowledge of collocations and academic literacy. He is also affiliated with McGill University, McGill Writing Centre of the Faculty of Continuing Studies where he serves as an Instructor.

Kris van de Poel (PhD Edinburgh University) is a professor in Applied Linguistics at the University of Antwerp where she coordinates international research at the Unit for Applied Language Studies. She is also an extraordinary professor at the School of Languages of North-West University, Potchefstroom campus. 


\section{APPENDICES}

APPENDIX A: Table 1: Correlations between TALL/TAG and Collocations

\begin{tabular}{|c|c|c|c|c|c|c|c|}
\hline & & $\begin{array}{l}\text { Tot- } \\
\text { Collocation }\end{array}$ & $\begin{array}{l}\text { TAG/TALL result } \\
\text { out of } 100 \%\end{array}$ & 2000_Tot & 3000_Tot & 5000_Tot & AWL_Tot \\
\hline \multirow{3}{*}{ Tot-Collocation } & $\begin{array}{l}\text { Pearson } \\
\text { Correlation }\end{array}$ & 1 & & $.756^{* *}$ & $.809^{* *}$ & $.750^{* *}$ & $.796^{* *}$ \\
\hline & Sig. (2-tailed) & & .000 & .000 & .000 & .000 & .000 \\
\hline & & 109 & 92 & 109 & 109 & 109 & 109 \\
\hline \multirow{2}{*}{$\begin{array}{l}\text { TAG/TALL result } \\
\text { out of } 100 \%\end{array}$} & $\begin{array}{l}\text { Pearson } \\
\text { Correlation }\end{array}$ & $.367^{* *}$ & 1 & .199 & $.348^{* *}$ & $.348^{* *}$ & $.223^{*}$ \\
\hline & Sig. (2-tailed) & .000 & & .056 & .001 & .001 & .033 \\
\hline \multirow{3}{*}{ 2000_Tot } & $\begin{array}{l}\mathrm{N} \\
\text { Pearson } \\
\text { Correlation }\end{array}$ & $\begin{array}{l}92 \\
.756^{* *}\end{array}$ & $\begin{array}{l}98 \\
.199\end{array}$ & $\begin{array}{l}93 \\
1\end{array}$ & $\begin{array}{l}92 \\
.542^{* *}\end{array}$ & $\begin{array}{l}92 \\
.363^{* *}\end{array}$ & $\begin{array}{l}92 \\
.453^{* *}\end{array}$ \\
\hline & Sig. (2-tailed) & .000 & .056 & & .000 & .000 & .000 \\
\hline & & 109 & 93 & 110 & 109 & 109 & 109 \\
\hline \multirow{3}{*}{ 3000_Tot } & $\begin{array}{l}\text { Pearson } \\
\text { Correlation }\end{array}$ & $.809^{* *}$ & $.348^{* *}$ & $.542^{* *}$ & 1 & $.527^{* *}$ & $.488^{* *}$ \\
\hline & Sig. (2-tailed) & .000 & .001 & .000 & & .000 & .000 \\
\hline & & 109 & 92 & 109 & 109 & 109 & 109 \\
\hline \multirow{3}{*}{ 5000_Tot } & $\begin{array}{l}\text { Pearson } \\
\text { Correlation }\end{array}$ & $.750^{* *}$ & $.348^{* *}$ & $.363^{* *}$ & $.527^{* *}$ & 1 & $.474^{* *}$ \\
\hline & Sig. (2-tailed) & .000 & .001 & .000 & .000 & & .000 \\
\hline & & 109 & 92 & 109 & 109 & 109 & 109 \\
\hline \multirow{3}{*}{ AWL_Tot } & $\begin{array}{l}\text { Pearson } \\
\text { Correlation }\end{array}$ & $.796^{*}$ & $.223^{*}$ & $.453^{* *}$ & $.488^{* *}$ & $.474^{* *}$ & 1 \\
\hline & Sig. (2-tailed) & .000 & .033 & .000 & .000 & .000 & \\
\hline & $\mathrm{N}$ & 109 & 92 & 109 & 109 & 109 & 109 \\
\hline
\end{tabular}

**. Correlation is significant at the 0.01 level (2-tailed).

*. Correlation is significant at the 0.05 level (2-tailed). 
APPENDIX B: Figures illustrating correlations at word bands

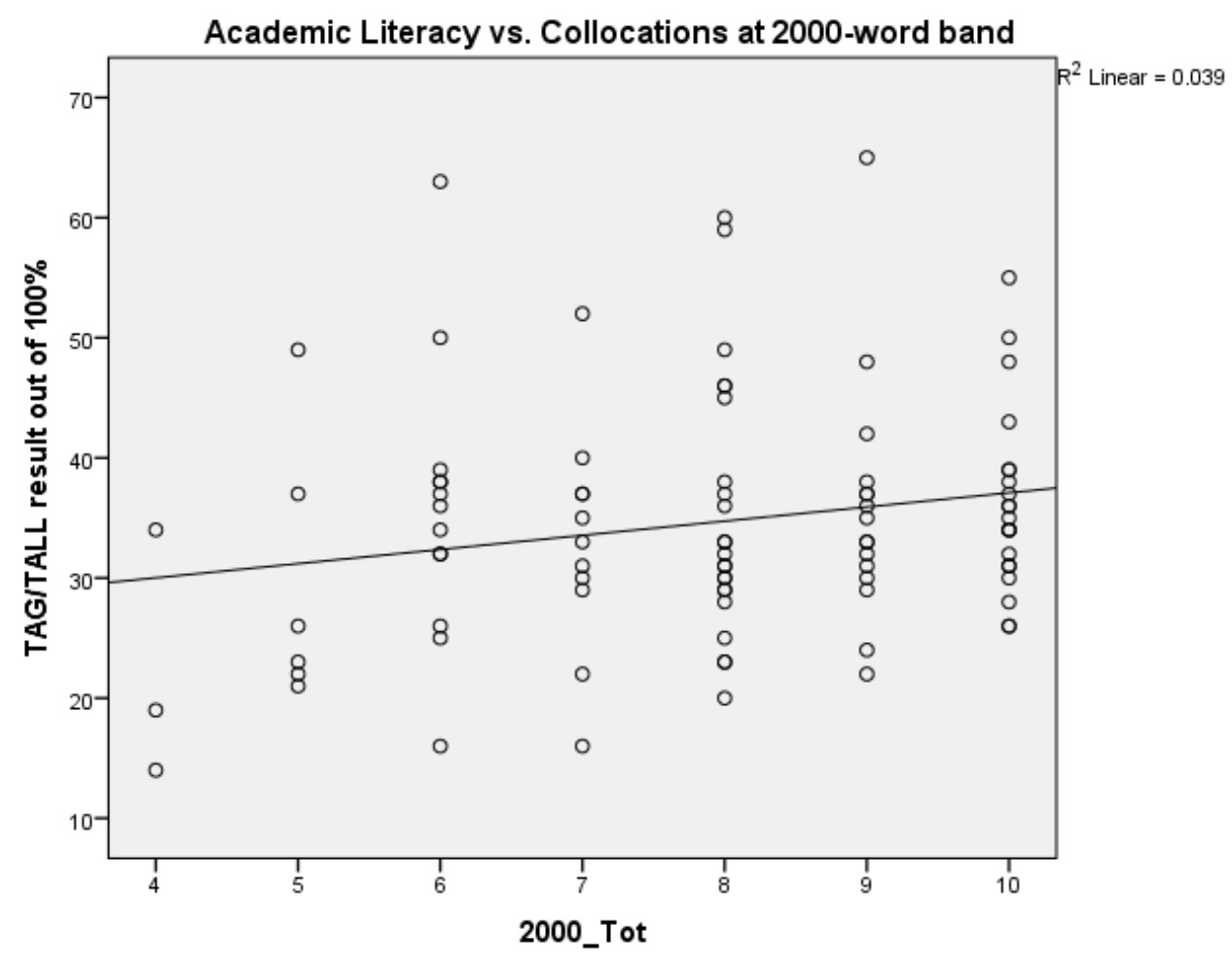

Figure 2. Growth of Collocations at the 2000-word and Academic Literacy

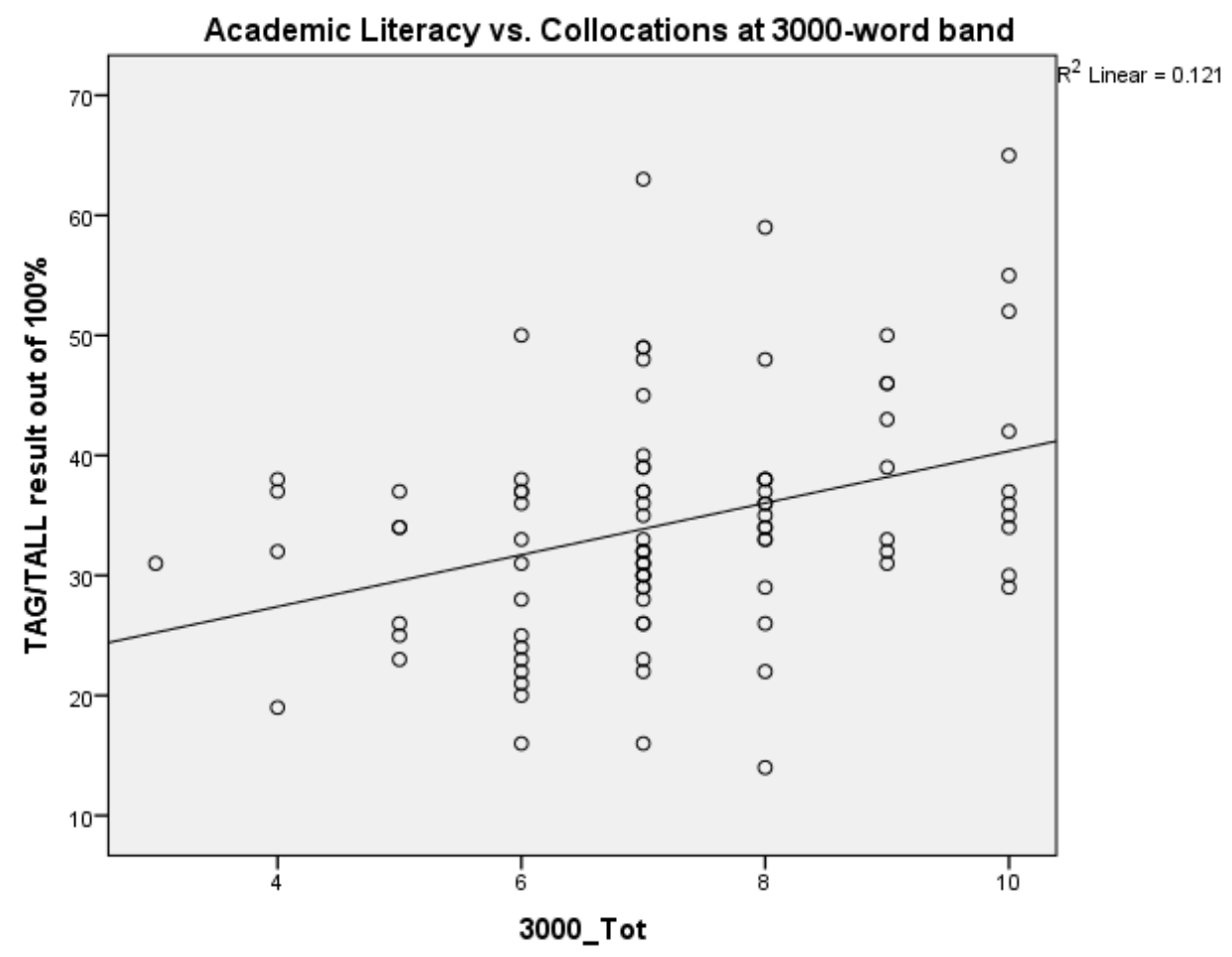

Figure 3. Growth of Collocations at the 3000-word and Academic Literacy

Per Linguam 2016 32(2):66-81 


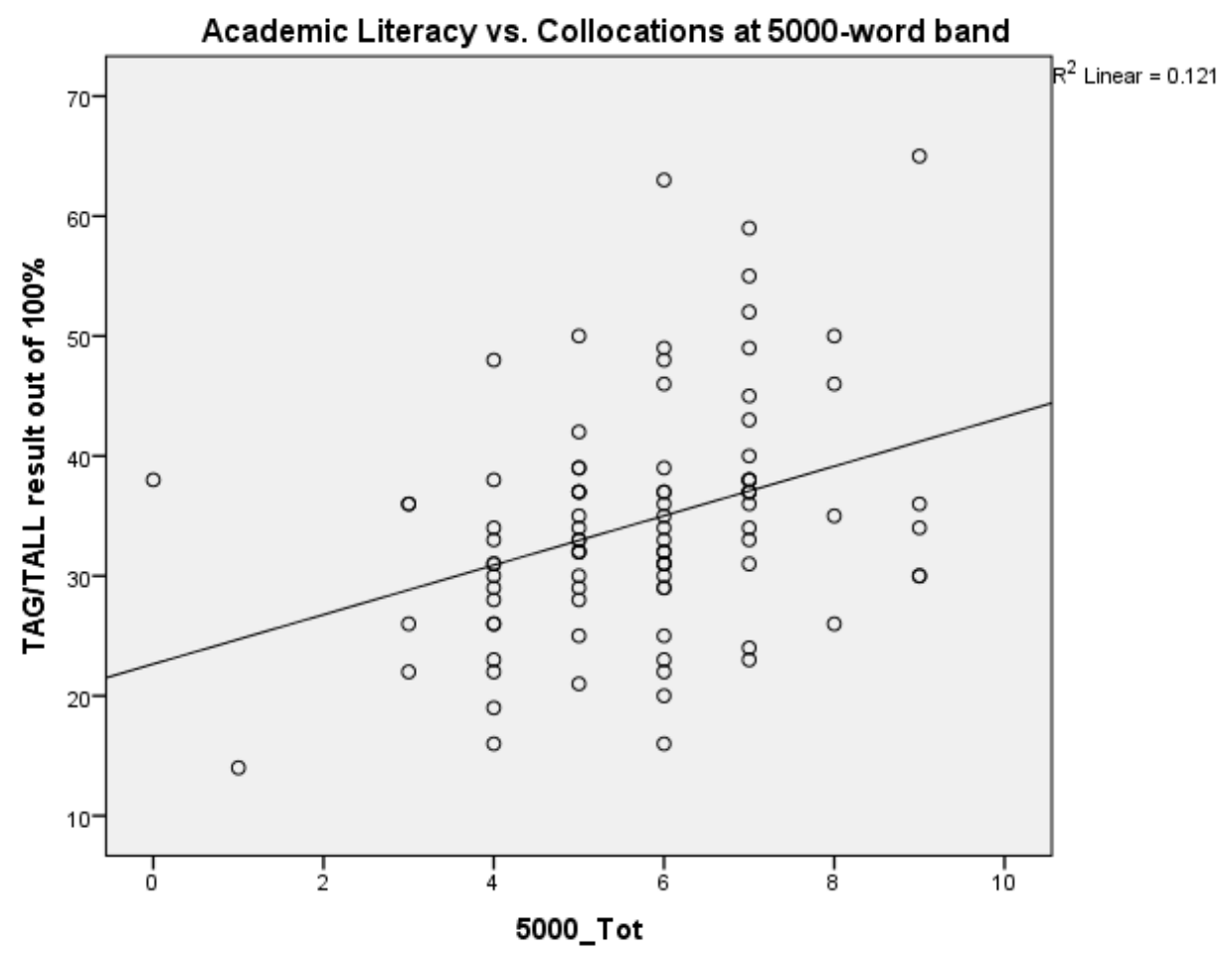

Figure 4. Growth of Collocations at the 5000-word and Academic Literacy

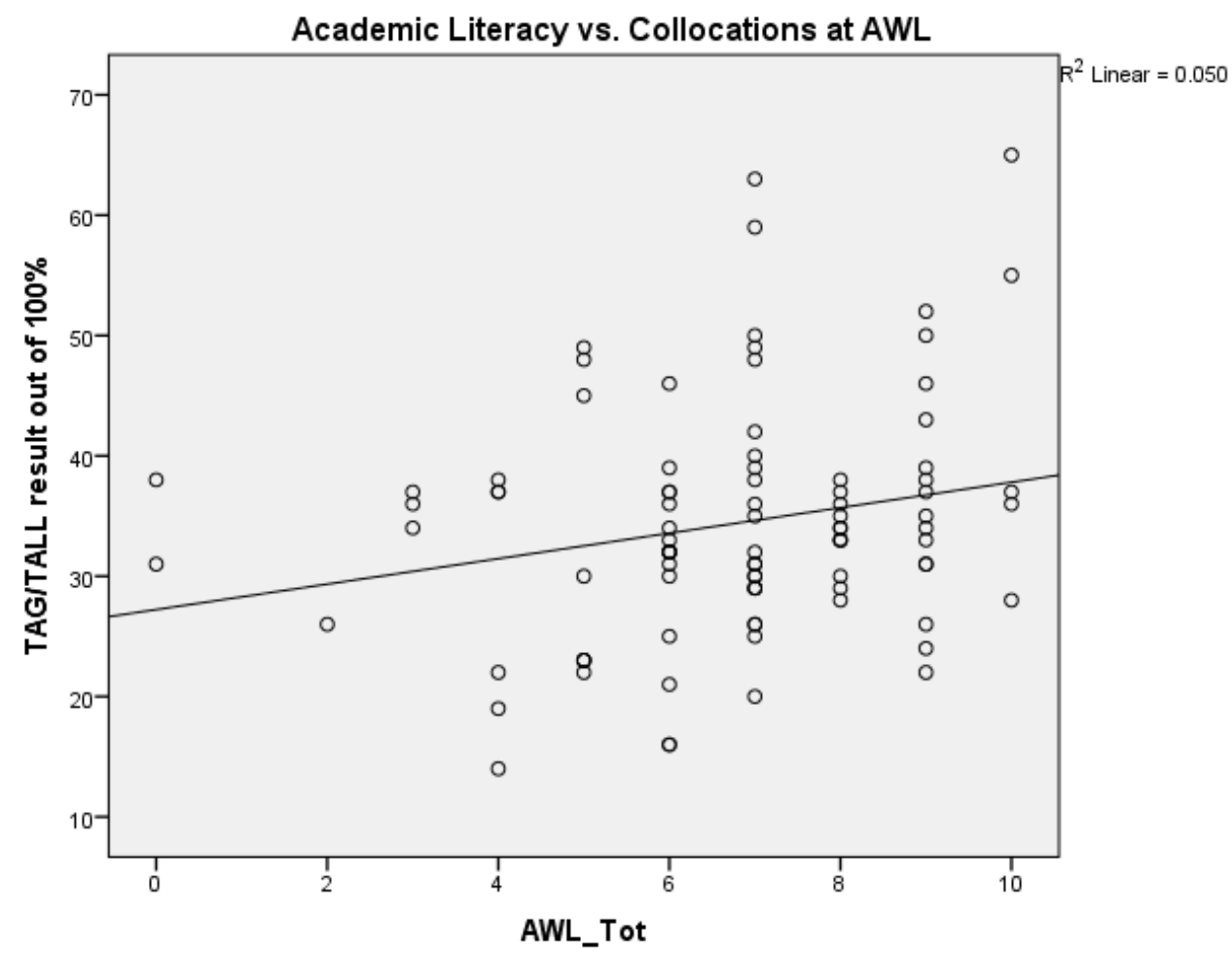

Figure 5. Growth of Collocations at the AWL and Academic Literacy

Per Linguam 2016 32(2):66-81 